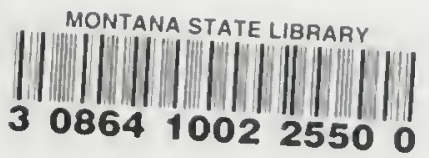

\title{
BIOLOGICAL INTEGRITY OF LOGAN CREEK (FLATHEAD-STILLWATER TMDL PLANNING AREA) BASED ON THE STRUCTURE AND COMPOSITION OF THE BENTHIC ALGAE COMMUNITY
}

\author{
Prepared for: \\ State of Montana \\ Department of Environmental Quality \\ P.O. Box 200901 \\ Helena, Montana 59620-0901 \\ Contract Officer: Rosie Sada \\ DEQ Contraet No. 200012-10
}

STATE DOCUMENTS COLLECTIL

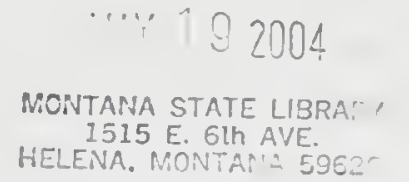

Prepared by:

Loren L. Bahls, Ph.D.

Hannaea

1032 Twelfth Avenue

Helena, Montana 59601

January 12, 2004 
잉 


\section{Summary}

In July 2003, periphyton samples were collected from 3 sites on Logan Creek in the Flathead-Stillwater River TMDL planning area in northwestern Montana for the purpose of assessing whether this stream is water-quality limited and in need of TMDLs. The samples were collected following MDEQ standard operating procedures, processed and analyzed following standard methods for periphyton, and evaluated following modified USEPA rapid bioassessment protocols for wadeable streams.

Diatom metries indicated minor stress but lull support of aquatic life uses at all three sites on Logan Creek. An elevated percentage of motile diatoms indicated minor sedimentation at the upper two stations: Logan Creek above Cyclone Creek and Logan Creek above Star Mleadows. A large number of Achnanthidium mimutissimum at these sites also indicated minor disturbance, which probably resulted from natural causes. These two sites supported virtually identical diatom assemblages, which had excellent species richness and diversity for a mountain stream. The non-diatom algae at these sites were a healthy mix of cyanobacteria, green algae, and the chrysophyte Vaucheria (above Cyclone Creek only). Nitrogen was probably the limiting nutrient above Star Meadows.

The periphyton community at the Tally Lake Campground was significantly different from the communities at the upstream sites. The Tally Lake sample was dominated by two genera of nitrogen-fixing cyanobacteria (Rivularia and Nostoc), which indicate that nitrogen was probably the limiting nutrient here. The rare and pollution-sensitive brown alga Heribaudiella was abundant here and ranked third in biovolume. The diatom assemblage at Tally Lake Campground was dominated by attached species that are sensitive to organic pollution. A large percentage of Cocconeis placentula indicated minor stress that was probably natural and related to the prevailing substrate at this site. Although diatom metrics indicate that this site had good biological integrity, modal categories for diatom ecological attributes indicate that the site had significantly higher alkalinity, larger concentrations of inorganic nutrients (phosphorus), and smaller concentrations of dissolved oxygen than the two upstrean sites. 


\section{Introduction}

This report evaluates the biological integrity ${ }^{1}$, support of aquatic life uses, and probable causes of stress or impairment to aquatic communities in Logan Creek in the Flathead-Stillwater River TMDL Planning Area of northwestern Montana. The purpose of this report is to provide information that will help the State of Montana determine whether Logan Creek is water-quality limited and in need of TMDLs.

The federal Clean Water Act directs states to develop water pollution control plans (Total Maximum Daily Loads or TMDLs) that set limits on pollution loading to water-quality limited waters. Water-quality limited waters are lakes and stream segments that do not meet waterquality standards, that is, that do not fully support their beneficial uses. The Clean Water Act and USEPA regulations require each state to (1) identify waters that are water-quality limited, (2) prioritize and target waters for TMDLs, and (3) develop TMDL plans to attain and maintain water-quality standards for all water-quality limited waters.

Evaluation of aquatic life use support in this report is based on the species composition and structure of periphyton (aka benthic algae, phytobenthos) communities at three sites on Logan Creek that were sampled in early July of 2003. Periphyton is a diverse assortment of simple photosynthetic organisms called algae that live attached to or in close proximity of the stream bottom. Some algae form long filaments or large gelatinous colonies that are conspicuous to the unaided eye. But most algae, including the ubiquitous diatoms, can be seen and identified only with the aid of a microscope. The periphyton community is a basic biological component of all aquatic ecosystems. Periphyton accounts for much of the primary production and biological diversity in Montana streams (Bahls et al. 1992). Plafkin et al. (19S9) and Barbour et al. (1999) list several advantages of using periphyton in biological assessments.

\footnotetext{
'Biological integrity is defined as "the ability of an aquatic ecosystem to support and maintain a balanced. integrated, adaptive community of organisms having a species composition, diversity. and functional organization comparable to that of natural habitats within a region" (Karr and Dudley 19\$1).
} 


\section{Project Area and Sampling Sites}

The project area is located within Level IV ecoregion 15i (Salish Mountains), which is part of the Northern Rockies Ecoregion in Flathead County, Montana (Woods et al. 1999). The Salish Mountains are forested and underlain by Precambrian Belt rocks. Its crests are mantled with volcanic ash. rarely exceed an elevation of 7,000 feet, and lack the alpine zones that occur in higher mountains. Average precipitation is about 20 to 50 inches per year. The region was glaciated by the Cordilleran ice sheet, which modified physiography and deposited till. Climax vegetation consists of Douglas-fir, subalpine fir, grand fir, and Engelmann spruce forests. The main land uses are logging, recreation, watershed, and wildlife habitat.

Periphyton samples were collected at three sites on Logan Creek upstream from Tally Lake (Table 1). Logan Creek is a tributary of the Stillwater River (USGS HUC 17010210), which is a tributary of the Flathead River. Logan Creek is classified B-1 in the Montana Surface Water Quality Standards.

\section{Methods}

Periphyton samples were collected following standard operating procedures of the MDEQ Planning, Prevention, and Assistance Division. Using appropriate tools, microalgae were scraped, brushed, or sucked from natural substrates in proportion to the importance of those substrates at each study site. Macroalgae were picked by hand in proportion to their abundance at the site. All collections of microalgae and macroalgae were pooled into a common container and preserved with Lugol's (IKI) solution.

The samples were examined to estimate the relative abundance of cells and rank by biovolume of diatoms and genera of soft (non-diatom) algae according to the method described in Bahls (1993). Soft algae were identified using Smith (1950), Prescott (1962, 1978), John et al. (2002), and Wehr and Sheath (2003). These books also served as references on the ecology of the soft algae, along with Palmer $(1969,1977)$. 
After the identification of soft algae, the raw periphyton samples were cleaned of organic matter using sulfuric acid, potassium dichromate, and hydrogen peroxide. Then permanent diatom slides were prepared using Naphrax ${ }^{\mathrm{TM}}$, a high refractive index mounting medium, following Standard Methods for the Examination of Water and Wastewater (APHA 1998). At least 300 diatom cells (600 valves) were counted at random and identified to species. The following were the main taxonomic references for the diatoms: Krammer and Lange-Bertalot 1986, 1988, 1991a, 1991b; Lange-Bertalot 1993, 2001; Krammer 1997a, 1997b, 2002; Reichardt 1997, 1999. Diatom naming conventions followed those adopted by the Integrated Taxonomic Information System (http://www.itis.usda.gov). Van Dam et al. (1994) was the main ecological reference for the diatoms.

The diatom proportional counts were used to generate an array of diatom association metrics. A metric is a characteristic of the biota that changes in some predictable way with increased human influence (Barbour et al. 1999). Diatoms are particularly useful in generating metrics because there is a wealth of information available in the literature regarding the pollution tolerances and water quality preferences of common diatom species (e.g., Lowe 1974, Beaver 1981, Lange-Bertalot 1996, Van Dam et al. 1994).

Values for selected metrics were compared to biocriteria (numeric thresholds) developed for streams in the Rocky Mountain ecoregions of Montana (Table 2). These criteria are based on metric values measured in least-impaired reference streams (Bahls et al. 1992) and metric values measured in streams that are known to be impaired by various sources and causes of pollution (Bahls 1993). The criteria in Table 2 are valid only for samples collected during the summer field season (June 21-September 21) and distinguish among four levels of stress or impairment and three levels of aquatic life use support: (1) no impairment or only minor impairment (full support); (2) moderate impairment (partial support); and (3) severe impairment (nonsupport). These impaiment levels correspond to excellent, good, fair, and poor biological integrity, respectively. In cold, high-gradient mountain streams, natural stressors will often mimic the effects of man-caused impaiment on some metric values. 


\section{Quality Assurance}

Several steps were taken to assure that the study results are accurate and reproducible. Upon receipt of the samples, station and sample attribute data were recorded in the Montana Diatom Database and the samples were assigned a unique number, e.g., 2954-01. The first part of this number (2954) designates the sampling site (Logan Creek at Tally Lake Campground) and the second part (01) designates the number of periphyton samples that that have been collected at this site for which data have been entered into the Montana Diatom Database.

Sample observations and analyses of soft (non-diatom) algae were recorded in a lab notebook along with information on the sample label. A portion of the raw sample was used to make duplicate diatom slides. The slides used for the diatom proportional counts will be deposited in the Montana Diatom Collection at the University of Montana Herbarium (MONTU) in Missoula. Duplicate slides will be retained by Hannaea in Helena. Diatom proportional counts have been entered into the Montana Diatom Database.

\section{Results and Discussion}

Results are presented in Tables 3, 4 and 5, which are located near the end of this report following the references section. Appendix A contains a diatom report for each sample. Each diatom report ineludes an alphabetical list of diatom species in that sample and their percent abundances, and values for 65 different diatom metries and ecological attributes.

\section{Sample Notes}

Tally Lake Campground. Fine particulate organic matter was very abundant. Numerous fungal hyphae were present.

Above Star Meadows. Fine particulate organic matter and fine inorganic sediment were both very abundant. 
Above Cyclone Creek. Large amounts of fine particulate organic matter and fine to medium inorganic sediment were present. Macrophytes and moss were both present.

\section{Non-Diatom Algae (Table 3)}

Tally Lake Campground. This site was dominated by cyanobacteria with heterocysts (Rivularia and Nostoc), which are capable of fixing atmospheric (molecular) nitrogen. The abundance of these algae indicates probable nitrogen-limiting conditions at this site. The rare and pollution-sensitive brown alga Heribaudiella was abundant here and ranked third in biovolume, followed by diatoms, which were frequent and ranked fourth (Table 3). An occasional red alga (Audouinella) was found in this sample but green algae (i.e., Stigeoclonitum) were rare. Collectively, the non-diatom algal assemblage at this site indicates cool flowing waters with low nutrient (especially nitrogen) concentrations.

Above Star Meadows. The algal flora at this site was similar to the flora downstream at the Tally Lake Campground, except that one of the dominant cyanobacteria here (Oscillatoria) does not fix nitrogen under aerobic conditions. However, Nostoc was a co-dominant at this site and this genus does fix nitrogen. Diatoms were abundant and ranked third at this site, followed by three genera of green algae, which ranged in abundance from abundant (Closterium) to common (Chaetophora) to rare (Cosmarium). Collectively, the algae at this site also indicate cool flowing waters with low concentrations of inorganic nutrients.

Above Cyclone Creek. This site was dominated by the green alga Closterium, the chrysophyte Vancheria, and by diatoms (Table 3). The cyanobacterium Oscillatoria was also abundant here and ranked fourth. Green algae were more common and the number of genera of green algae (7) was much larger here than at the two downstream stations. This, coupled with an absence of nitrogen-fixing cyanobacteria, indicates elevated nitrogen concentrations compared to the downstream sites. Dominance by Vaucheria indicates steady flows of cool waters. 


\section{Diatoms (Table 4)}

The 12 major diatom specics from Logan Creek are included in pollution tolerance classes 3 and 2 and are either sensitive to organic pollution or only somewhat tolerant of organic pollution (Table 4). Nonc of the major diatom species in Logan Creek are most tolerant of organic pollution (pollution tolerance class $=1$ ).

Tally Lake Campground. The most abundant diatom species at this site were Cocconeis placentula and Achnanthidium minutissimum (Table 4). These are both attached species that resist disturbance and both are sensitive to elevated levels of organic pollution. The third most abundant diatom at this site (Encyonopsis krammeri) is seldom reported from North America but also sensitive to organic pollution. Overall, diatom metrics indicated good diversity and equitability, low organic nutrients, and acceptable sediment levels for a mountain stream.

Only a slightly elevated percent abundance of the dominant species ( $C$. placentula) indicated minor natural stress at this site. This diatom is adapted to living attached to rocks, and its dominance here is probably substrate related. Otherwise, diatom metrics indicated excellent biological integrity and full support of aquatic life uses. The Tally Lake site shared about $40 \%$ of its diatom flora with the next upstream site (above Star Meadows), which indicates a minor to moderate change in ecological conditions between the two sites.

Above Star Meadows and Above Cyclone Creek. These two sites had virtually identical diatom floras ( $70 \%$ community similarity) and will be discussed together. A somewhat elevated percentage of motile diatoms indicated minor impaiment from sedimentation at both sites (Table 4). Both sites also supported large numbers of Achnanthidium minutissimum, which indicates minor physical, chemical, or biological disturbance. Such disturbance may be caused by substrate scour, toxic metals, and/or invertebrate grazing. Since no abnormal diatom cells were observed at this site, metals toxicity may be ruled out. Overall, diatom metrics indicated good diversity and equitability, low organic nutrients, and the absence of toxic chemicals. Other than minor sedimentation and disturbance, diatom metrics indicated excellent biological integrity 
and full support of aquatic life uses at both sites. The site above Cyclone Creek shared only $38 \%$ of its diatom flora with the site at Tally Lake Campground.

\section{Modal Categories (Table 5)}

Several ecological attributes assigned by Stevenson and Van Dam et al. (1994) were selected from the diatom reports in the appendix and modal categories of these attributes were extracted to characterize water quality tendencies in Logan Creek (Table 5).

The majority of diatoms at all three sites on Logan Creek were non-motile nitrogen autotrophs that prefer fresh waters and low BOD levels. However, the modal category for oxygen demand declined from "continuously high" at the upstream sites to "moderate" at the downstream site, indicating a decline in the availability of dissolved oxygen. The modal categories for $\mathrm{pH}$ and trophic state also shifted from the upstream sites to the downstream site, indicating significant increases in alkalinity and concentrations of inorganic phosphorus at Tally Lake Campground. 


\section{References}

APHA. 1998. Standard Methods for the Exammation of Water and Wastewater. 20 Edition. American Public Health Association, Washington, D.C.

Bahls, L.L. 1979. Benthic diatom diversity as a measure of water quality. Proceedings of the Montana Academy of Sciences 38:1-6.

Bahls, L.L. 1993. Periphyton Bioassessment Methods for Montana Streams (revised). Montana Department of Health and Environmental Sciences, Helena.

Bahls, L.L., Bob Bukantis, and Steve Tralles. 1992. Benchmark Biology of Montana Reference Streams. Montana Department of Health and Environmental Sciences, Helena.

Barbour, M.T., J. Gerritsen, B.D. Snyder, and J.B. Stribling. 1999. Rapid Bioassessment Protocols for Use In Streams and Wadeable Rivers: Periphyton, Benthic Macroinvertebrates and Fish. Second Edition. E1'A/841-B-99-002. U.S. Environmental Protection Agency, Office of Water, Washington, D.C.

Beaver, Janet. 1981. Apparent Ecological Characteristics of Some Common Freshwater Diatoms. Ontario Ministry of The Environment, Technical Support Section, Don Mills, Ontario.

Hieber, Maggi, C.T. Robinson, S. R. Rushforth, and Urs Uehlinger. 2001. Algal communities associated with different alpine stream types. Arctic, Antarctic, and Alpine Research 33(4):447-456.

Johansen, J.R. 1999. Diatoms of Aerial Habitats. Chapter 12 in Stoermer, E.F., and J.P. Smol (eds.), The Diatoms: Applications For the Environmental and Earth Sciences, Cambridge University Press, New York.

John, D.M., B.A. Whitton, and A.J. Brook (eds.). 2002. The Freshwater Algal Flora of the British Isles: An Identification Guide to Freshwater and Terrestrial Algae. Cambridge University

Karr, J.R., and D.R. Dudley. 1981. Ecological perspectıves on water quality goals. Environmental Management 5:55-69.

Kawecka, B. 1990. The effect of flood-control regulation of a montane stream on the communities of sessile algae. Acta Hydrobiology 32:345-354.

Krammer, Kurt. 1997a. Die cymbelloiden Diatomeen: Eine Monographie der weltweit bekannten Taxa. Teil 1. Allgemeines and Encyonema Part. J. Cramer, Berlin.

Krammer, Kurt. 1997b. Die cymbelloiden Diatomeen: Eine Monographie der weltweit bekannten Taxa. Teil 2. Encyonema part., Encyonopsis and Cymbellopsis. J. Cramer, Berlin.

Krammer, Kurt. 2002. Cymbella. Volume 3 in Diatoms of Europe, Horst Lange-Bertalot, ed. A.R.G. Gantner Verlag K.G., Germany.

Krammer, K., and H. Lange-Bertalot. 1986. Bacillariophyceae, Part 2, Volume I: Naviculaceae. In Ettl, H., J Gerloff, H. Heynig, and D. Mollenhauer (eds.), Freshwater Flora of Middle Europe. Gustav Fischer Publisher, New York.

Krammer, K., and H. Lange-Bertalot. 1988. Bacillariophyceae, Part 2, Volume 2: Bacillariaceae, Epithemiaceae, Surirellaceae. In Ettl, H., J. Gerloff, H. Heynig, and D. Mollenhauer (eds.), Freshwater Flora of Middle Europe. Gustav Fischer Publisher, New York. 
Krammer, K., and H. Lange-Bertalot. 1991 a. Bacillariophyceae, Part 2, Volume 3: Centrales, Fragilariaceae, Eunotiaceae. In Ettl, H., J. Gerloff, H. Heynig, and D. Mollenhauer (eds.), Freshwater Flora of Middle Europe. Gustav Fischer Publisher, Stuttgart.

Krammer, K., and H. Lange-Bertalot. 199lb. Bacillariophyceae, Part 2, Volume 4: Achnanthaceae, Critical Supplement to Navicula (Lineolatae) and Gomphonema, Complete List of Literature for Volumes 1-4. In Ettl, H., G. Gartner, J. Gerloff, H. Heynig, and D. Mollenhauer (eds.), Freshwater Flora of Middle Europe. Gustav Fischer Publisher, Stuttgart.

Lange-Bertalot. Horst. 1979. Pollution tolerance of diatoms as a criterion for water quality estimation. Nova Hedwigia 64:285-304.

Lange-Bertalot, Horst. 1993. 85 new taxa and much more than 100 taxonomic clarifications supplementary to Susswasserflora von Mitteleuropa Vol. 2/1-4. J. Cramer, Berlin.

Lange-Bertalot, Horst. 1996. Rote Liste der limnischen Kieselalgen (Bacillariophyceae) Deutschlands. Schr.-R. f. Vegetationskde., H. 28, pp. 633-677. BfN, Bonn-Bad Godesberg.

Lange-Bertalot, Horst. 2001. Navicula sensu stricto: 10 Genera Separated from Navicula sensu lato; Frustulia. Volume 2 in Diatoms of Europe, Horst Lange-Bertalot, ed. A.R.G. Gantner Verlag K.G., Germany.

Lowe, R.L. 1974. Environmental Requirements and Pollution Tolerance of Freshwater Diatoms. EPA-670/4-74-005. U.S. Environmental Protection Agency, National Environmental Research Center, Office of Research and Development, Cincinnati, Ohio.

McFarland, B.H., B.H. Hill, and W.T. Willingham. 1997. Abnormal Fragilaria spp. (Bacillariophyceae) In streams impacted by mine drainage. Journal of Freshwater Ecology 12(1):141-149.

Nicholls, K.H., and D.E.Wujek. 2003. Chrysophycean Algae. Chapter 12 (pp. 471-509) in Wehr, J.D., and R.G. Sheath (eds.), Freshwater Algae of North America: Ecology and Classification. Academic Press, New York.

Palmer, C.M. 1969. A composite rating of algae tolerating organic pollution. Journal of Phycology 5:78-82.

Palmer, C.M. 1977. Algae and Water Pollution: An Illustrated Manual on the ldentification, Significance, and Control of Algae in Water Supplies and in Polluted Water. EPA-600/9-77-036.

Plafkin, J.L., M.T. Barbour, K.D. Porter, S.K. Gross, and R.M. Hughes. 1989. Rapid Bioassessment Protocols for Use in Rivers and Streams: Benthic Macroinvertebrates and Fish. EPA 440-4-89-001.

Prescott, G.W. 1962. Algae of the Western Great Lakes Area. Wm. C. Brown Company, Dubuque, lowa.

Prescott, G.W. 1978. How to Know the Freshwater Algae. Third Edition. Wm. C. Brown Company Publishers, Dubuque, Iowa.

Reichardt, Erwin. 1997. Taxonomische Revision des Artenkomplexes um Gomphonema pumilum (Bacillariophyta). Nova Hedwigia 65(1-4):99-129.

Reichardt, Erwin. 1999. Zur Revision der Gattung Gomphonema. A.R.G. Gantner Verlag, Distributed by Koeltz Scientific Books, Konigstein, Germany.

Renfro, H.B., and D.E. Feray. 1972. Geological Highway Map of the Northern Rocky Mountain Region. American Association of Petroleum Geologists, Tulsa, Oklahoma. 
Smith, G.M. 1950. The Fresh-Water Algae of The United States. McGraw-Hill Book Company, New York.

Stevenson, R.J., and Y. Pan. 1999. Assessing Environmental Conditions in Rivers and Streams with Diatoms. Chapter 2 in Stoemer, E.F., and J.P. Snol (eds.), The Diatons: Applications For the Environmental and Earth Sciences, Cambridge University Press, New York.

Stewart, W.D.P., P. Rowell, and A.N. Rai. 1980. Symbiotic Nitrogen-Fixing Cyanobacteria. Pp. 239-277 in Stewart, W.D.P., and J. Gallo (eds.), Nitrogen Fixation, Academic Press, New York.

USDA. 1976. Climax Vegetation of Montana (map). U.S. Department of Agriculture, Soil Conservation Service, Cartographic Unit, Portland.

USEPA. 2000. Level 111 Ecoregions of the Continental United States (map). National Health and Environmental Effects Research Laboratory, U.S. Environmental Protection Agency, Corvallis, Oregon.

Van Dam, Ilerman, Adrienne Mertens, and Jos Sinkeldam. 1994. A coded checklist and ecological indicator values of freshwater diatoms from The Netherlands. Netherlands Journal of Aquatic Ecology 28(1):1 17-133.

Weber, C.1. (ed.). 1973. Biological Field and Laboratory Methods for Measuring the Quality of Surface Waters and Effluents. EPA-670/4-73-001. U.S. Environmental Protection Agency, National Environmental Research Center, Office of Research and Development, Cincinnati, Ohio.

Wehr, J.D., and R.G. Sheath. 2003. Freshwater Algae of North America: Ecology and Classification. Academic Press, New York.

Whittaker, R.H. 1952. A study of summer foliage insect communities in the Great Smoky Mountains. Ecological Monographs 22:1-44.

Woods, A.J., Omernik, J.M., Nesser, J.A., Shelden, J., and S.H. Azevedo. 1999. Ecoregions of Montana (color poster with map), U.S. Geological Survey, Reston, Virginia. 


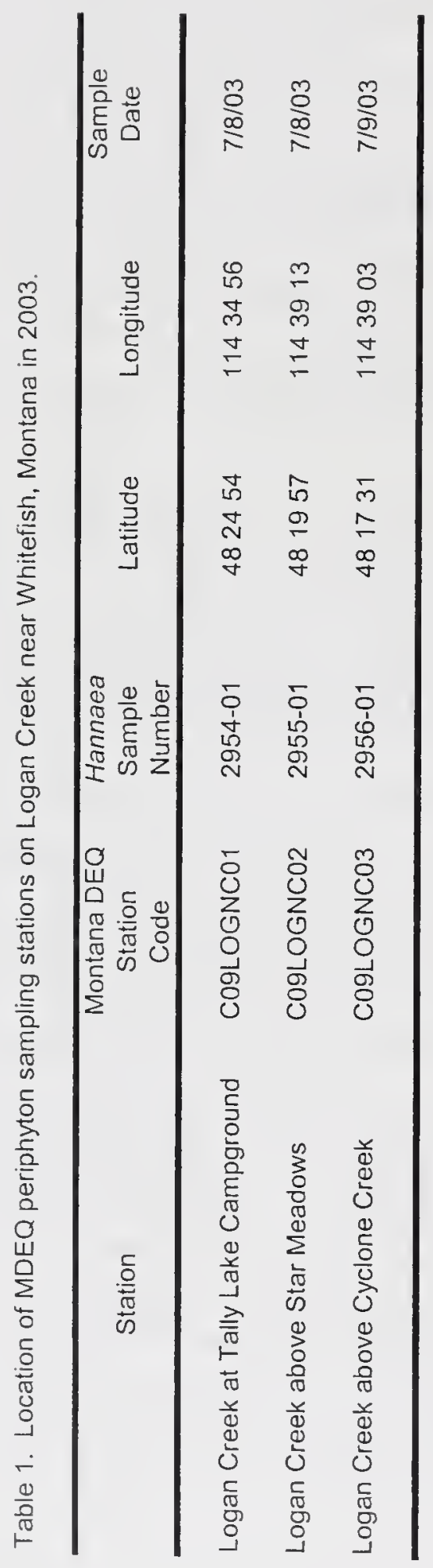




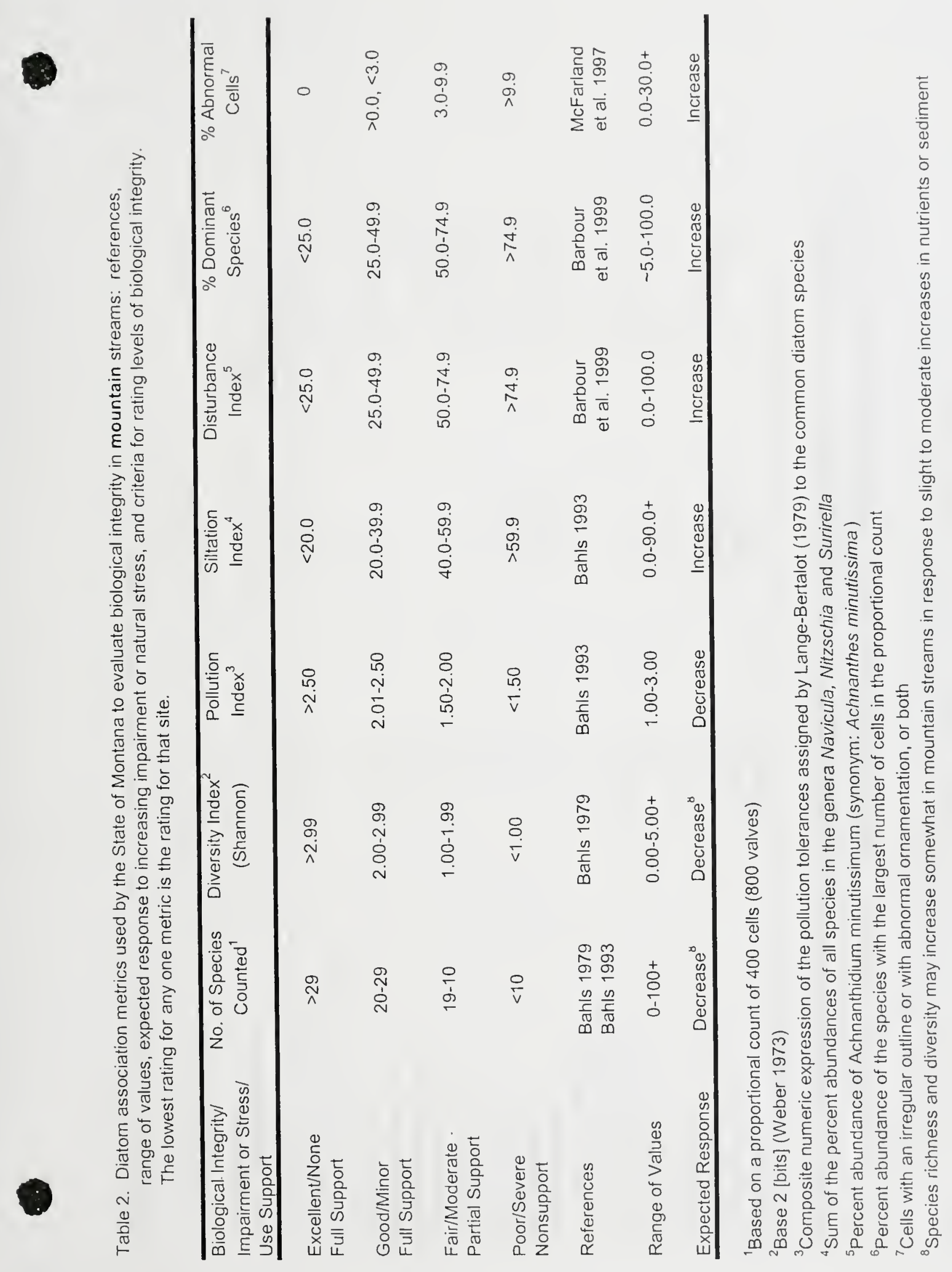




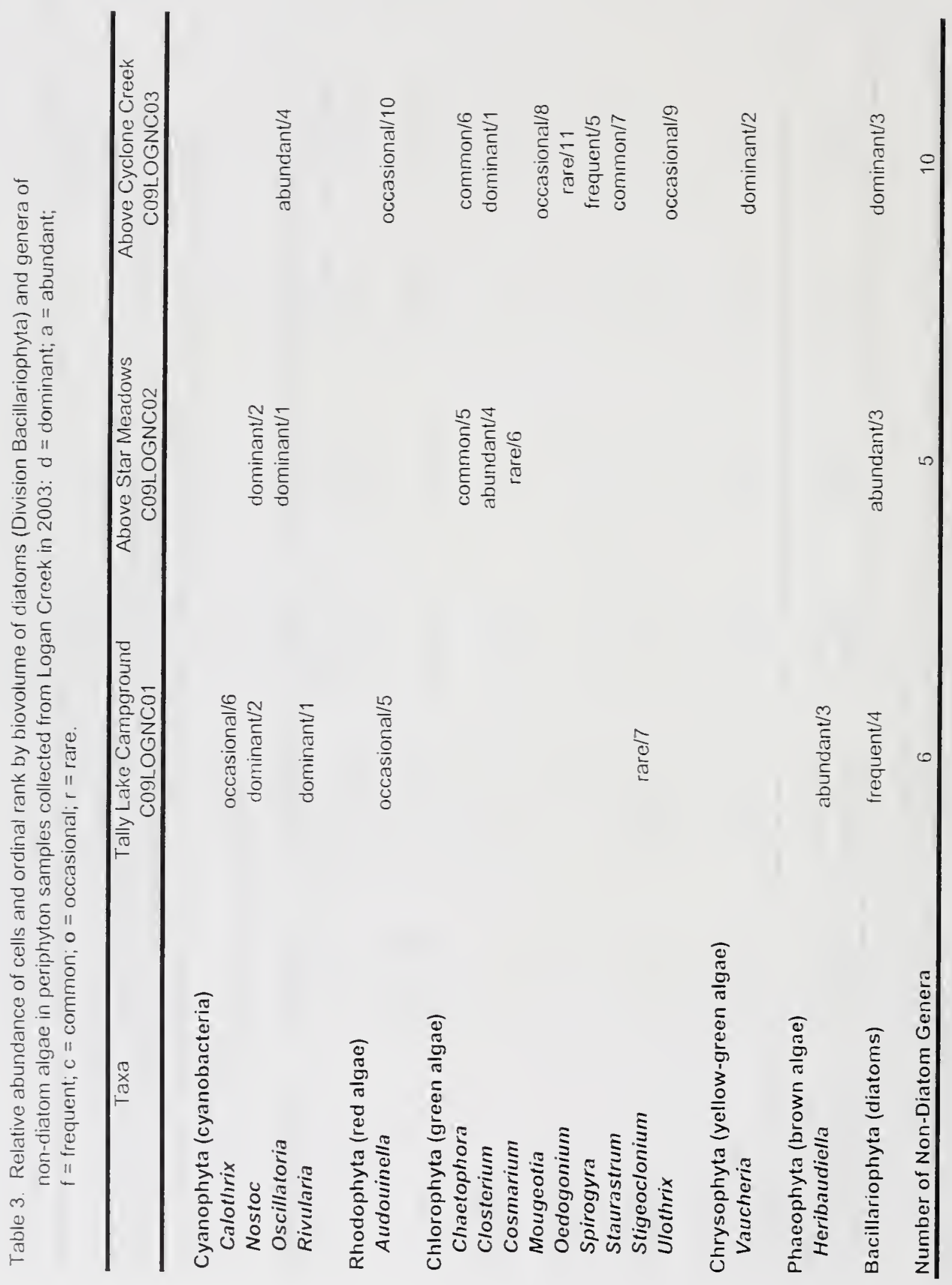




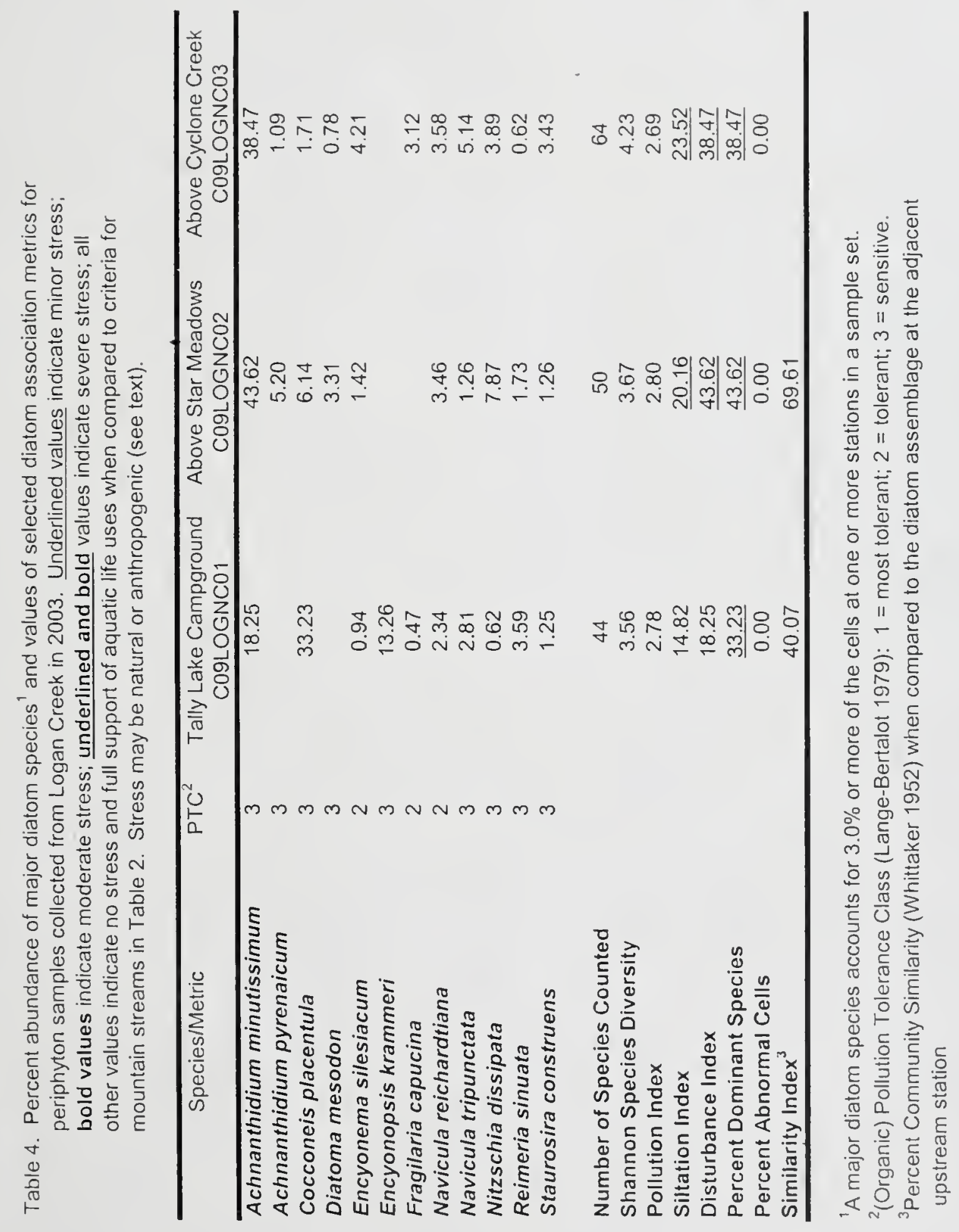




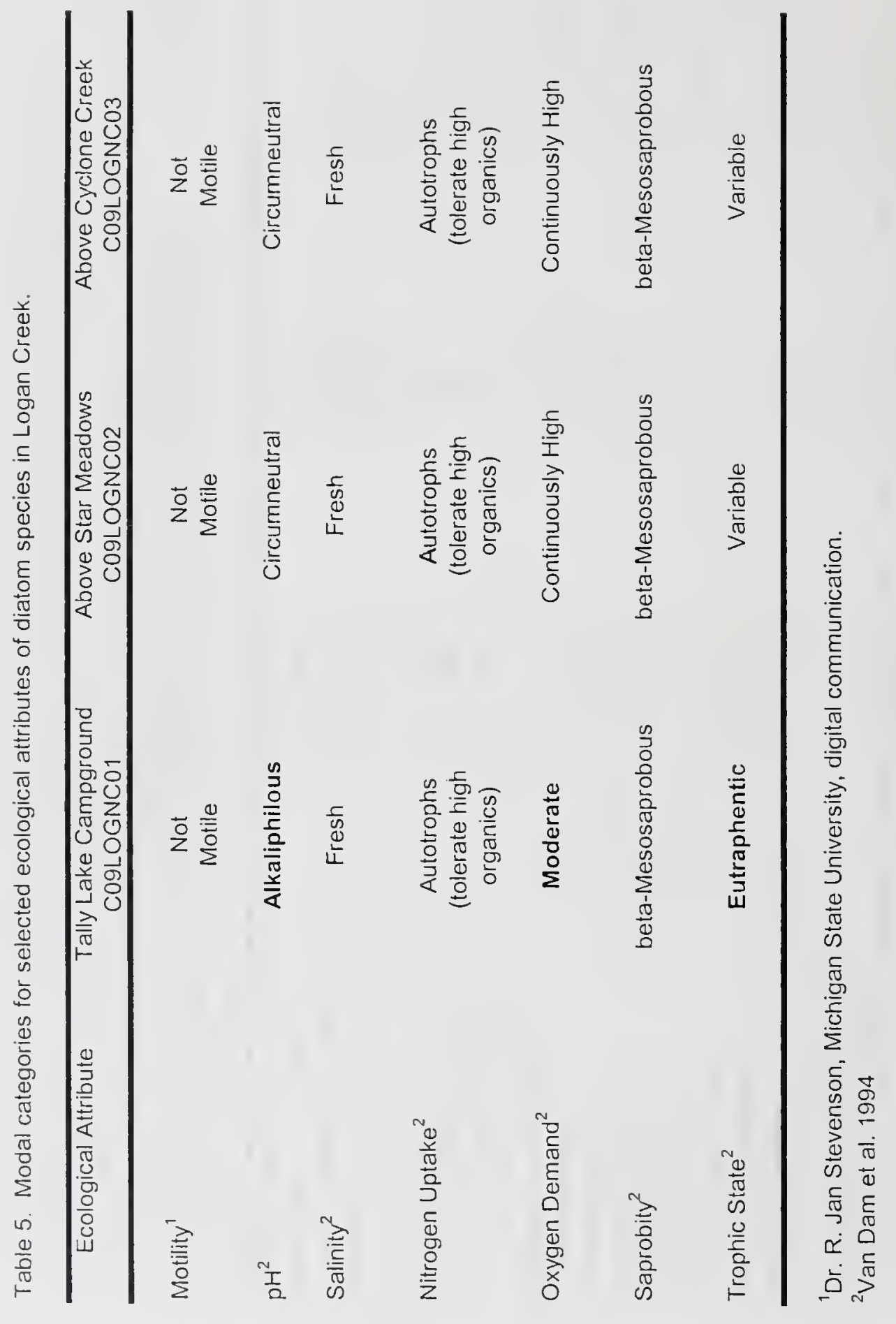

